\title{
Effect of Land Configuration and Nutrient Management on Yield and Economics of Greengram under Sodic Soil
}

\author{
N. Karikalan", S. Anandha Krishnaveni, S. Avudaithai and S. Nithila \\ Department of Agronomy, Anbil Dharmalingam Agricultural College and Research Institute, \\ Trichy, Tamil Nadu, India \\ *Corresponding author
}

Keywords

Greengram, Land configuration,

Nutrient

management and

Foliar spray

Article Info

Accepted:

14 November 2020

Available Online:

10 December 2020

\begin{abstract}
A B S T R A C T
Field experiment was conducted during kharif season of 2019 at Anbil Dharmalingam Agriculture College and Research Institute, Trichy to find out the effect of different land configuration and nutrient management on green gram under sodic condition. The experiment was laid out in factorial randomized block design with three replications. The land configuration factor consists of the three treatments viz., flat bed, ridges and furrows and broad bed furrow system. The second factor nutrient management comprising of five treatments like $100 \% \mathrm{RDF}+1 \% \mathrm{DAP}, 100 \% \mathrm{RDF}+1 \% \mathrm{MAP}, 75 \% \mathrm{RDF}+2 \% \mathrm{MAP}$, $100 \% \mathrm{RDF}+1 \% \mathrm{MKP}, 75 \% \mathrm{RDF}+2 \% \mathrm{MKP}$. The results revealed that significantly higher number of pods per plant, number of seeds per plant and yield were recorded under broad bed furrow over farmer's practice of flatbed method. Among the nutrient management practices $\mathrm{N}_{4}-100 \% \mathrm{RDF}+1 \% \mathrm{MKP}$ foliar spray twice at flower initiation and pod formation stage significantly highest growth parameters (pods per plant, number of seeds per plant, 100 seed weight, grain yield and haulm yield) were observed than farmer's practice. Results indicated that broad bed furrow with nutrient management practice of $100 \% \mathrm{RDF}+1 \% \mathrm{MKP}$ has the potential to enhance the productivity green gram under sodic condition.
\end{abstract}

\section{Introduction}

Greengram (Vigna radiata L.), is a third important pulse crop after chickpea and red gram. It contains 25 per cent protein which is two to three times more than cereals. In Tamil $\mathrm{Nadu}$, the area under greengram is $1.01 \mathrm{~L}$ ha, the production of $0.608 \mathrm{~L} \mathrm{t}$ and productivity of $605 \mathrm{~kg} \mathrm{ha}^{-1}$. It is one of the important short duration grain legumes which improve the soil and biodiversity.
Several research workers have notified that land configuration provides better environment for uniform germination, growth, flowering and pod development which eventually increase the yield. Sodic soil having waterlogging problem even for a short period proves detrimental to the crop of greengram particularly during the early growth period to avoid this select suitable land configuration becomes important for successful cultivation of green gram. Raised bed method of sowing has been reported 
helpful to reduce the effects of temporary water logging and salt injury on plants (Dhimmar, 2003 and Akbar et al., 2007). The raised bed zone of broad bed and furrow system is provide better aerated with lower penetration resistance and proper crop emergence.

Proper nutrient management is also one of the important factor for sustained production on sodic soil due to their poor fertility status. Sodic soil contain sodium salts which decreases substrate water potential and thus restricts water and nutrient uptake by the roots, high salinity and $\mathrm{pH}$ may also cause ionic imbalance and toxicity in plants(Bahadhur et al., 2012).Application of plant nutrients through foliar spray resulted in efficient absorption. Keeping this in view, a study was conducted with an objective to find out the suitable land configuration and nutrient management practices in green gram.

\section{Materials and Methods}

A field experiment was conducted atAnbil Dharmalingam Agriculture College and Research Institute, Trichy during kharif season 2019. The experimental soil was sandy clay loam in texture and alkaline in reaction. Fifteen treatment combinations were tried with three levels of land configuration viz., flat bed, ridges and furrows and broad bed furrow system. Five levels of nutrient management namely farmer's practice of 100 $\% \mathrm{RDF}+2 \% \mathrm{DAP}, 100 \% \mathrm{RDF}+1 \% \mathrm{MAP}$, $75 \% \mathrm{RDF}+2 \% \mathrm{MAP}, 100 \% \mathrm{RDF}+1 \%$ MKP, $75 \%$ RDF + $2 \%$ MKP were imposed in Factorial Randomised Block Design with three replications. VBN $(\mathrm{Gg}) 2$ green gram variety was used in the study.

As per the schedule treatments were imposed. The foliar spray solutions of DAP, MKP and MAP were prepared by dissolving $10 \mathrm{~g}$ and 20 $\mathrm{g}$ of fertilizers in one litre of water to get $1 \%$ and $2 \%$ concentration, respectively. MKP and MAP fertilizers are highly water soluble salts which completely dissolved in water but DAP granules were dissolved in little quantity of water and allowed to settle overnight and the supernatant solution was taken for spraying after dilution with remaining quantity of water. Yield attributes and yield were recorded in five plants at harvesting stage. Collected data were statistically analysed using ANOVA.

\section{Results and Discussion}

\section{Land configuration}

The land configuration methods had significant effect on number of number of pods per plant, number of seeds per plant and yield. However it doesn't have no significant effect on test weight i.e., 100 seed weight.

Number of pods per plant was significantly higher under broad bed method of sowing as compared to flatbed method of sowing (Table 1). Similarly among the different land configuration methods, broad bed furrow system significantly recorded the maximum number of seeds per pod. This might be due to improved soil aeration, nutrients availability and better soil environment under broad bed furrow ultimately resulted in better growth and development of green gram crop in sodic condition. In turn this reflected in higher number of pods per plant and number of seeds per pod. The present findings are in agreement with those reported by Rathore $e t$ al.,(2010), Jadhav et al., (2012) and NICRA, 2014.

Further, higher number of pods per plant under broad bed furrow method of sowing resulted in significantly higher seed yield. Similar trend was also observed for haulm yield of greengram because of higher dry matter accumulation per plant under broad 
bed furrow method. This might be due to lower salt injury to plants under broad bed method of sowing as plant root had less chance to revelation with soluble salts which improved soil environment, root development, optimum moisture -air equilibrium throughout the crop growth period besides easily supply of available nutrients to greengram reflected in higher seed and haulm yields. The results are in accordance with finding of Joshi et al., (2018) and Yadav et al., (2019).

Table.1 Effect of Land configuration and Nutrient Management on yield attributes, yield and economics of green gram

\begin{tabular}{|c|c|c|c|c|c|c|c|}
\hline Treatment & $\begin{array}{c}\text { Number } \\
\text { of pods/ } \\
\text { plant }\end{array}$ & $\begin{array}{c}\text { Number } \\
\text { of seeds } \\
\text { / pod }\end{array}$ & $\begin{array}{c}\text { Test } \\
\text { weight } \\
\text { (g) }\end{array}$ & $\begin{array}{c}\text { Grain } \\
\text { yield } \\
\left(\mathrm{Kg} \mathrm{ha}^{-1}\right)\end{array}$ & $\begin{array}{c}\text { Haulm } \\
\text { yield } \\
\left(\mathrm{kg} \mathrm{ha}^{-1}\right)\end{array}$ & $\begin{array}{l}\text { Net } \\
\text { income } \\
\text { (Rs.) }\end{array}$ & $\begin{array}{l}\text { B:C } \\
\text { Ratio }\end{array}$ \\
\hline \multicolumn{8}{|l|}{ Land configuration } \\
\hline $\mathbf{L}_{1}$ - Flat Bed & 20.87 & 9.99 & 2.9 & 540.2 & 1430.2 & 12511 & 1.5 \\
\hline $\mathrm{L}_{2}$ - Ridges and Furrows & 29.42 & 11.19 & 3.1 & 761.3 & 1794.4 & 23244 & 1.8 \\
\hline $\mathbf{L}_{3}$-Broad Bed Furrow & 31.6 & 11.97 & 3.2 & 854.6 & 1952.8 & 29955 & 2.0 \\
\hline SEd & 0.66 & 0.24 & 0.14 & 20.31 & 63.54 & - & - \\
\hline C.D $(P=0.05)$ & 1.34 & 0.51 & NS & 41.61 & 130.16 & - & - \\
\hline \multicolumn{8}{|l|}{ Nutrient management } \\
\hline $\mathrm{N}_{1}-100 \% \mathrm{RDF}+2 \% \mathrm{DAP}$ & 28.26 & 10.94 & 3.1 & 730.1 & 1721.89 & 22944 & 1.8 \\
\hline $\mathrm{N}_{2}-100 \% \mathrm{RDF}+1 \% \mathrm{MAP}$ & 29.27 & 11.49 & 3.2 & 792.3 & 1912.56 & 26110 & 1.9 \\
\hline $\mathrm{N}_{3}-75 \% \mathrm{RDF}+2 \% \mathrm{MAP}$ & 22.87 & 9.82 & 2.7 & 600.8 & 1438.33 & 15207 & 1.6 \\
\hline $\mathrm{N}_{4}-100 \% \mathrm{RDF}+1 \% \mathrm{MKP}$ & 30.26 & 12.33 & 3.3 & 801.4 & 1996.22 & 26794 & 2.1 \\
\hline $\begin{array}{l}\mathrm{N}_{5}-75 \% \mathrm{RDF}+2 \% \\
\text { MKP }\end{array}$ & 25.83 & 10.67 & 2.97 & 651.7 & 1560.00 & 18460 & 1.7 \\
\hline SEd & 0.85 & 0.31 & 0.14 & 26.22 & 82.03 & - & - \\
\hline C.D(P=0.05) & 1.74 & 0.64 & 0.28 & 53.72 & 168.04 & - & - \\
\hline
\end{tabular}

\section{Nutrient management}

Application of $100 \% \mathrm{RDF}+1 \% \operatorname{MKP}\left(\mathrm{N}_{4}\right)$ observed significantly higher yield attributes and yield over other treatments. Among the nutrient management, application of $100 \%$ $\mathrm{RDF}+1 \% \mathrm{MKP}$ observed significantly maximum number of pods per plant, seeds per pod and 100 seed weight and it was followed by $100 \% \mathrm{RDF}+1 \% \mathrm{MAP}$ as compared to farmer's practice of $100 \% \mathrm{RDF}+2 \% \mathrm{DAP}$. This might be due to the excess application of $\mathrm{K}$ as MKP reduce negative effect of sodium salts and also increase uptake of nitrogen which attributed to better growth of plant which resulted in higher production of photosynthates were utilized by plant for development of sink under adequate supply of nutrients through recommended of fertilizer with foliar application phosphorus fertilizer gave higher number of pods per plant, number of seeds per pod and 100 seed weight under sodic condition. These results are in conformity with those of Himani et al., (2017) and Bulut et al., (2011).

Similarly, seed yield and haulm yield were also recorded significantly higher with application of $100 \%$ RDF + $1 \%$ MKP over farmer's practice of $100 \% \mathrm{RDF}+2 \% \mathrm{DAP}$. The higher yield under these treatments might be due to cumulative effect of better yield 
attributes (number of pods per plant, seeds per pod and 100 seed weight) and higher nutrient uptake by green gram under sodic condition. The present findings were in accordance with those of Nawange et al., (2011). Similarly Khan et al., (2006) reported foliar application of potassium significantly increased yield

\section{Economic}

Economics is therefore most criteria for the farmers while adopting to a new technology. Broad bed furrow method of sowing recorded higher net returns and benefit cost ratio over flatbed method of sowing. Application of $100 \% \mathrm{RDF}+1 \% \mathrm{MKP}$ recorded higher net returns and benefit cost ratio as compared to other treatments. This mainly due to maximum yield and productivity under these treatments leads to the higher net returns and benefit cost ratio. Similar findings were in close vicinity of Choudhary et al., (2013).

The present study concluded that soil sodicity can be overcome with land configuration and nutrient management practices. Sodic soil have a major impact on greengram productivity for sustainable farming system and sodification can also extend into subsoil layers posing serious problems for plant root development and remedial action. On the basis field experiment results, sowing in the broad bed furrow with application of $100 \%$ $\mathrm{RDF}+1 \% \mathrm{MKP}$ as foliar spray may be recommended to enhance the productivity of green gram under sodic soil condition.

\section{References}

Akbar, G., Hamilton, G., Hussain, Z. and Yasin, M. 2007. Problem and potential raised bed cropping systems in Pakistan. Pakistan Journal of Water Resource, 11(1): 11-15.

Bahadhur, D.D.Tiwari, J.Mishra and B.R.Gupta. (2012). Effect of integrated nutrient management on Yield, Microbial Population and Changes in Soil Properties under Rice-Wheat Cropping System in Sodic Soil, Journal of Indian Society of Soil Science, Vol. 60, No. 4, pp 326-329.

Bulut, F., Akinci, S., Eroglu, A. (2011): Growth and uptake of sodium and potassium in Broad Bean (Vicia faba L.) under Salinity Stress. Comm. Soil Sci. Plant Anal. 42, 945-961.

Choudhary, H. R., Sharma, O. P., Singh, R. K., Singh, K., Kumar, R. and Yadav,L. 2013. Influence of organic manure and chemical fertilizer on nutrient uptake, yield and profitability of mungbean (Vigna radiate (L.) Wilczek). Madras Agricultural Journal 100(4-6): 339-341.

Dhimmar, S. K. 2003. Response of kharif cowpea (Vigna unguiculate L.) to land configuration and biofertilizer under South Gujarat conditions. M.Sc. (Agri.) Thesis submitted to Gujarat Agricultural University, Sardarkrushinagar.

Himani B. Patel, K.A. Shah, M.M. Barvaliya and Patel, S.A. 2017. Response of Greengram (Vigna radiata L.) To Different Level of Phosphorus and Organic Liquid Fertilizer. Int.J.Curr.Microbiol.App.Sci. $\quad$ 6(10): 3443-3451.

Jadhav JA, Patil DB, Ingole PG.2012. Effect of mechanization with different land configuration on yield and in situ moisture conservation of soybean. International Journal of Agricultural Sciences; 8(1): 2012.

Joshi, J.R., V.M. Patel, H.L. Barad, S.M. Macwan and Javid Ehsas. 2018. Effect of Land Configuration and Fertilizer Management Practices on Growth, Yield and Yield Attributes and Economics of Summer Cowpea (Vigna unguiculata L.) under South Gujarat Condition. Int.J.Curr.Microbiol.App.Sci. $\quad 7(01)$ : 1148-1155. 
Nawange, D. D., Yadav, A. S. and Singh, R. V. 2011. Effect of phosphorus and sulphur application on growth, yield attributes and yield of chickpea. Legume Research, 34(1): 48-50.

NICRA. 2014. Evaluation of in-situ water harvesting technologies for dry land crops, water harvesting technology to cope with climate variability in dry land agriculture in Tamil Nadu. Progress Report 2013-2014, TNAU, Coimbatore,
201-202.

Rathore R. S, Singh R, Nawange, D. D. 2010. Effect of land configuration on growth and yield of black gram. Legume Research. 2010; 33(4):274-278.

Yadav AC, Husain K, Verma VK, Tiwari US, Khan N, Siddiqui M Z. 2019. Effect of land configuration and nutrient management on growth and yield of hybrid maize. Journal of Pharmacognosy and Phytochemistry; 8(4):602-606.

\section{How to cite this article:}

Karikalan, N., S. Anandha Krishnaveni, S. Avudaithai and Nithila, S. 2020. Effect of Land Configuration and Nutrient Management on Yield and Economics of Greengram under Sodic Soil. Int.J.Curr.Microbiol.App.Sci. 9(12): 2125-2129.

doi: https://doi.org/10.20546/ijcmas.2020.912.249 